\title{
Particle Size Changes in Rumens of Cattle Grazing Kansas Flint Hills Range
}

\author{
J.R. FORWOOD, C.E. OWENSBY, AND G. TOWNE
}

\begin{abstract}
A ruminally fistulated Hereford steer and heifer graxing Kansas Flint Hills range were used with the objective of determining forage particle breakdown and distribution in different rumen sites over several hours post feeding during seasons of differing forage quality. During the first year, samples were taken after an overnight fast from 3 rumen sites and from feces early on the sample morning (AM sample). The cattle were fed and sampled again 12 hours later (PM sample). During year two, the cattle were sampled immediately as they came from the native pasture (PRE sample) in addition to the 2 other sample times. Samples were wet-sieved through a series of 5 screens to separate particle sizes. Material from each screen was dried, weighed and expressed as a percentage of the total of all screens. In the rumen, relative amounts of coarse particles generally decreased while amounts of smaller particles generally increased with advancing season. Forage maturity had similar effects on fecal particle sizes. Particles in the feces were more uniform in size than particles in the rumen.
\end{abstract}

Rumen turnover time is the time required for entrance of an amount of feed equal to that represented in the rumen. Increased turnover (i.e., lower rumen retention time, rapid passage rate, and greater roughage intake) yields more fermentation product to the ruminant, thereby increasing animal performance (Hungate 1966).

While specific gravity (Balch and Campling 1965) and shape (Troelsen and Campbell 1968) are factors regulating rate of passage of roughage out of the ruminoreticulum, the rate of roughage breakdown to sufficiently small size to pass through the reticuloomasal orifice is probably the most important factor (Balch and Campling 1965). Rumination and microbial digestion are the two principal processes involved in particle size reduction (Pearce and Moir 1964). Fine particles appear to pass through the reticuloomasal orifice rapidly while larger and longer particles are retained in the rumino-reticulum (Balch and Campling 1965, Welch and Smith 1978).

Authors are assistant professor and research agronomist, USDA-ARS, Crop Production Research Unit, University of Missouri, Columbia 65211; professor, range management and research associate Department of Agronomy, Throckmorton Hall, Kansas State University, Manhattan 66506.

This article is contribution No. 83-150-J, Department of Agronomy.

Manuscript accepted June 4, 1984.
Rumen particle size changes have been monitored over time using Medicago sp. (Silver et al. 1935) and milled oaten hay plus supplement (Pearce 1967). Evans et al. (1973) investigated particle size changes at 5 rumen sites over a 24-hour period when feeding an unnamed pasture hay. Only Troelsen and Campbell (1968) compared rumen particle size changes of hays [Medicago media Pers. var. (alfalfa) and Agropyron cristatum (L.) Gaertn. (crested wheatgrass)] of increasing maturity at differing rumen sites over 24 hours.

Apparently, no literature exists concerning particle distribution and breakdown in different rumen sites over several hours post feeding during seasons of differing forage quality. Our objective was to monitor forage particle size changes in rumens of cattle grazing native Kansas Flint Hills range forage.

\section{Materials and Methods}

The study area was located $8 \mathrm{~km}$ northwest of Manhattan, Kans. Vegetation was largely big bluestem (Andropogon gerardi Vitman), indiangrass [Sorghastrum nutans (L.) Nash.], and little bluestem (Andropogon scoparius Michx.) with numerous other warm-season grasses, forbs and woody species constituting the remainder.

This study coincided with a study of nutrient removal using the same cattle. Data were collected over a 2-year period biweekly during periods of changing forage quality and once per month during the dormant season (1979-81). A Hereford steer and a heifer, both ruminally fistulated and about 2.5 years old, were the experimental animals. They were penned and fasted with access to water the evening before the sample day. During year 1, samples were taken from 6 rumen sites similar to those described by Evans et al. (1973) (Fig. 1) and from feces early on the sample morning (AM sample) and again from the rumen 12 hours after feeding (PM sample) harvested range forage. During year 2 , the cattle were sampled immediately as they came from the native pasture (PRE sample), after an overnight fast (AM) and again 12 hours after feeding (PM) of harvested forage. Data presented are particle sizes present approximately 12 hours post feeding unless indicated as PRE sample. Forage offered to the cattle was cut with a sickle-bar mower either on the sample morning or the evening before. When 


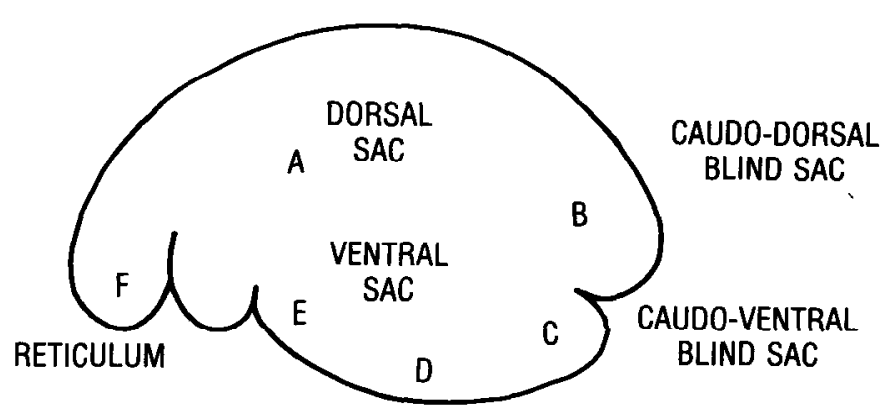

Fig. 1. Ruminoreticulum sample sites for the study of particle size changes in rumens of cattle grazing native Flint Hills range. $A$ and $B=$ Dorsal: $C$, $D$ and $E=$ Ventral $; F=$ Reticulum

cut the evening before, it was refrigerated overnight. The cattle were offered a known amount of forage for about 1 hour or until they ceased eating.

A closed plastic sample container $(50 \mathrm{ml}, 5 \mathrm{~cm}$ diameter $)$ with a tight fitting lid was inserted by hand in each location in the ruminoreticula. After being situated, the lid was removed. When digesta was of a fluid nature, material was allowed to flow freely into the container until full. If solid masses of digesta were present, they were raked into the container with the fingers with insufficient force to remove free liquid. When full, the cap was replaced and the container withdrawn. Feces samples for each animal were obtained by randomly sampling fresh deposits on the ground or by directly sampling the animals. Samples were stored in glass bottles with screw-cap lids. About $50 \mathrm{ml}$ of formaldehyde was added to prevent further microbial breakdown. Each sample was wet-sieved through a series of five screens arranged in order, coarse to fine (Table 1) on

Table 1. Screen sizes used as related to forage particle size descriptions in the ruminoreticulum particle size analysis wet-sieving process.

\begin{tabular}{llccc}
\hline $\begin{array}{l}\text { USA Series } \\
\text { equivalent }\end{array}$ & $\begin{array}{l}\text { Forage } \\
\text { particle size } \\
\text { description }\end{array}$ & $\begin{array}{c}\text { Standard } \\
\text { designation }\end{array}$ & $\begin{array}{c}\text { Nominal } \\
\text { wire } \\
\text { diameter }\end{array}$ & $\begin{array}{c}\text { Tyler screen scale } \\
\text { equivalent } \\
\text { designation }\end{array}$ \\
\hline No. 9 & coarse & 2.36 & $1.00 \mathrm{~mm}$ & 8 mesh \\
No. 16 & medium & $1.18 \mathrm{~mm}$ & $0.65 \mathrm{~mm}$ & 14 mesh \\
No. 30 & medium & $600 \mathrm{um}$ & $0.39 \mathrm{~mm}$ & 28 mesh \\
No. 50 & fine & $300 \mathrm{um}$ & $0.215 \mathrm{~mm}$ & 48 mesh \\
No. 200 & very fine & $75 \mathrm{um}$ & $0.035 \mathrm{~mm}$ & 200 mesh \\
\hline
\end{tabular}

a sieve shaker. Constant washing and shaking carried particles that would pass mesh surfaces to the lower screens. That process lasted for 2 intervals of 5 minutes each, interrupted by a washing of the material on each screen with distilled water. After sieving, remaining material was washed from each screen onto a $12.5-\mathrm{cm}$ tared filter paper and dried. Material from each screen was weighed and expressed as a percentage of the total of all screens.

Io facilitate statistical analysis, the 16 collection dates in both years were placed in 3 groups: (1) early season, (2) growing season, and (3) dormant season, based on similarities in cell wall, cellulose, lignin, and crude protein content of harvested forage (Table 2) over dates and traditional seasonal changes in the area. Rumen sites were grouped based on particle size similarity of past studies (Evans et al. 1973), and our own results. Sites A and B became 'dorsal', C, D and E became 'ventral, and sites $F$ and $M$ remained reticulum and feces, respectively.

Forage quality fractions were determined as outlined by Goering and VanSoest (1970). Micro-Kjeldahl nitrogen $(\mathrm{N})$ was measured colorimetriclly and crude protein estimated by $\mathrm{N} \times 6.25$.

Data were analyzed by analysis of variance. Means were separated using Duncan's multiple range test $(P<.10$ and .05$)$ (Duncan 1955). Separation of fecal and rumen particle size means within times or dates was done using the paired $T$-test (Steel and Torrie, 1960).

\section{Results and Discussion}

Influence of Years and Seasons on Rumen Particle Sizes

Percentages of coarse particles in the rumen 12 hours post feeding were greatest during early and growing seasons and least during the dormant season $(P<.10)$ (Fig. 2). That agrees with
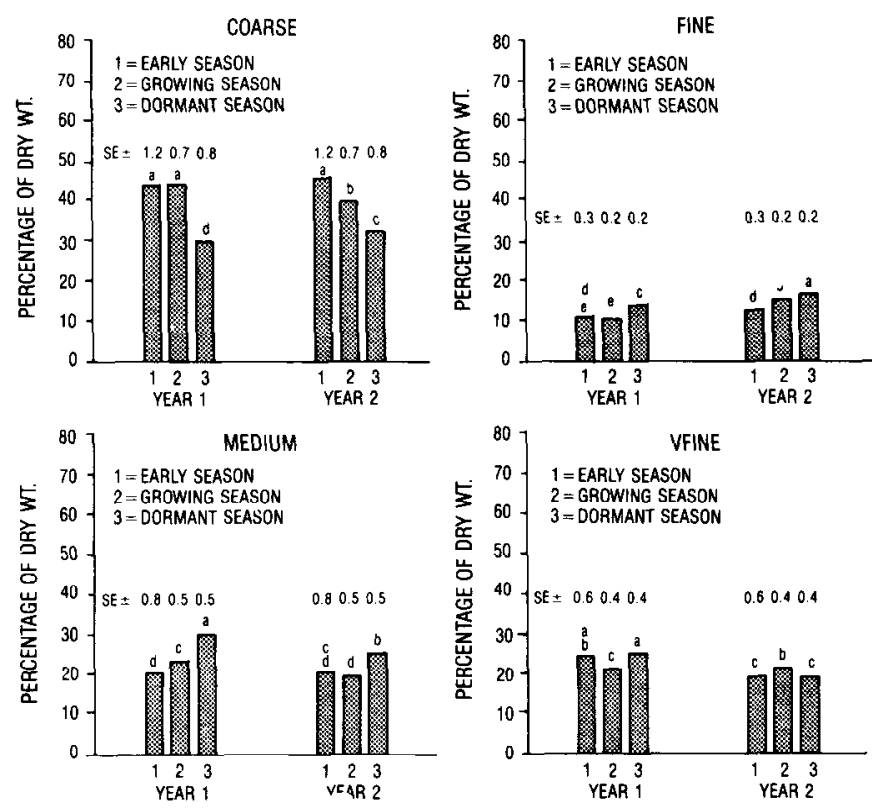

Fig. 2. Years I (1979-80) and 2 (1980-81) percentages of rumen digesta particles present in cattle rumens 12 hours post feeding during early, gruwing and dormant seasons. Bars with common letters are not significantly different $(\alpha=.10)$.

studics of digesta in sheep rumens when sheep were fed alfalfa and crested wheatgrass hays of increasing maturity (Troelson and Campbell 1968). We speculate several factors may be responsible for the large percentage of coarse particles at those times. Early season lush forage is usually high in soluble carbohydrate and may cause a depression of cellulolytic microorganisms in the rumen (Hungate 1966). Forage particles in fresh herbage boluses of Italian ryegrass (Lolium multiflorum) are larger than those of hay boluses (Gill et al. 1966). Most importantly, freshly ingested large herbage particles are almost constantly being added to the rumen.

Microbial attack and rumination rapidly reduce particle size during the early season because of low a mounts of cell wall constituents (Allinson and Osbourn 1970), lower lignin values (Patton and Geiseker 1942), and greater ease of cellulose digestion (Wilkins 1972). Large, pliable early or growing-season particles may pass the reticulo-omasal orifice more readily than stiff, mature dormantseason particles of the same size (Troelson and Campbell 1968). Although passage of early-season forage is rapid, addition to the rumen of newly ingested large particles also is rapid.

High percentage of coarse particles in the rumen do not reflect poor animal performance. Smith and Owensby (1978) show greater average daily gains (ADG) for steers from 1 May through 14 July than from 15 July through 30 October. Rapid particle breakdown facilitates rapid rate of passage of particles through the reticulo-omasal orifice and greater intake resulting in availability of more fermentable product to the ruminant and greater performance. Nutrient removal rate studies of cattle grazing Flint Hills range show faster removal of nutrients from the rumen during the growing season when compared to the dormant season (Forwood 1982). 
Table 2. Nutrient composition of Kansas Flint Hills range forage harvested and fed to cattle and grouping of dates into three seasons over two years (1979-81).

\begin{tabular}{|c|c|c|c|c|c|c|c|c|c|c|c|c|c|c|c|c|c|}
\hline & \multicolumn{17}{|c|}{ Year I $(1979-80)$} \\
\hline & $\begin{array}{c}\text { June } \\
15\end{array}$ & $\begin{array}{c}\text { July } \\
3\end{array}$ & $\begin{array}{c}\text { July } \\
20\end{array}$ & $\begin{array}{c}\text { Aug. } \\
2\end{array}$ & $\begin{array}{c}\text { Aug. } \\
16\end{array}$ & $\begin{array}{c}\text { Aug. } \\
30\end{array}$ & $\begin{array}{c}\text { Sept. } \\
11\end{array}$ & $\begin{array}{c}\text { Sept. } \\
27\end{array}$ & $\begin{array}{c}\text { Nov. } \\
9\end{array}$ & $\begin{array}{c}\text { Dec. } \\
6\end{array}$ & $\begin{array}{c}\text { Jan. } \\
4\end{array}$ & $\begin{array}{c}\text { Feb. } \\
4\end{array}$ & $\begin{array}{c}\text { Mar. } \\
6\end{array}$ & $\begin{array}{c}\text { Apr. } \\
1\end{array}$ & $\begin{array}{c}\text { May } \\
22\end{array}$ & $\begin{array}{c}\text { June } \\
5\end{array}$ & $\begin{array}{c}\text { June } \\
19\end{array}$ \\
\hline & \multicolumn{8}{|c|}{ Growing season } & \multicolumn{6}{|c|}{ Dormant season } & \multicolumn{3}{|c|}{ Early season } \\
\hline Cell solubles & 36.1 & 28.0 & 34.1 & 25.4 & 23.4 & 26.3 & 32.8 & 28.7 & 14.6 & 16.6 & 17.9 & 19.4 & 21.6 & 17.9 & 30.3 & 22.7 & 37.5 \\
\hline Cell walls & 63.9 & 72.0 & 65.9 & 74.6 & 76.6 & 73.7 & 67.2 & 71.3 & 85.4 & 83.4 & 82.1 & 80.6 & 78.4 & 82.1 & 69.7 & 77.3 & 62.5 \\
\hline Cellulose & 30.8 & 33.9 & 32.4 & 35.1 & 33.3 & 38.2 & 23.3 & 36.1 & 42.4 & 39.4 & 41.6 & 41.8 & 40.22 & 44.8 & 25.4 & 29.5 & 31.1 \\
\hline Lignin & 4.9 & 6.8 & 7.3 & 8.9 & 12.5 & 8.1 & 7.4 & 8.6 & 11.0 & 12.1 & 10.0 & 10.7 & 9.0 & 12.8 & 9.4 & 7.8 & 8.6 \\
\hline & $\begin{array}{c}\text { July } \\
8\end{array}$ & $\begin{array}{c}\text { July } \\
24\end{array}$ & $\begin{array}{c}\text { Aug } \\
11\end{array}$ & & $\begin{array}{c}\text { Aug. } \\
28\end{array}$ & $\begin{array}{c}\text { Sept. } \\
11\end{array}$ & $\begin{array}{c}\text { Sept. } \\
30\end{array}$ & $\begin{array}{c}\text { Oct. } \\
30\end{array}$ & $\begin{array}{c}\text { Dec. } \\
16\end{array}$ & $\begin{array}{c}\text { Jan } \\
15\end{array}$ & & $\begin{array}{l}\text { Feb. } \\
24\end{array}$ & $\underset{12}{\operatorname{Mar} .}$ & $\begin{array}{c}\text { Apr. } \\
14\end{array}$ & $\begin{array}{c}\text { May } \\
14\end{array}$ & $\begin{array}{c}\text { June } \\
2\end{array}$ & $\begin{array}{c}\text { June } \\
18\end{array}$ \\
\hline & \multicolumn{7}{|c|}{ Growing season } & \multicolumn{7}{|c|}{ Dormant season } & \multicolumn{3}{|c|}{ Early season } \\
\hline Cell solubles & 24.3 & 31.3 & 27.9 & & 24.0 & 24.3 & 25.7 & 19.4 & 20.0 & 24.8 & & 20.5 & 22.2 & 23.0 & 25.0 & 31.3 & 22.0 \\
\hline Cell walls & 75.7 & 68.7 & 72.1 & & 76.0 & 75.7 & 74.3 & 80.6 & 80.0 & 75.2 & & 79.5 & 77.8 & 76.9 & 75.0 & 68.7 & 78.1 \\
\hline
\end{tabular}

High lignin (Johnston and Waite 1965), cellulose (Wilkins 1972) and cell wall constituent percentages (Allison and Osbourn 1970), and lower crude protein (Akin et al. 1977) and digestibility (Wilkins 1972) all contribute to lower forage quality with maturity. Our analysis of Flint Hills range forage indicated similar trends (Table 2). When grazing mature forage, the ruminant experiences longer rumen retention times (Balch and Campling 1965), slower rates of passage, and lower intake (Blaxter et al. 1956, 1961), resulting in more complete breakdown of forage and smaller particle sizes due to extended rumination and microbial exposure (Fig. 2). Troelsen and Campbell (1968) also reported greater percentages of small particles with advancing forage maturity.

Percentages of coarse and fine particles in the rumen during year 1 did not vary $(P<10)$ with respect to early and growing seasons, indicating that rumen turnover during those seasons was similar (Fig. 2). However, coarse particles in the rumen during the year 2 growing season were significantly lower $(P<.10)$ and fine particle percentage higher than the early season (Fig. 2), suggesting the unusually hot and dry summer of 1980 hastened maturity of forage. Comparing early and growing season forage quality components, year 2 exhibited a greater decrease in cell solubles and increase in cell walls but a lower percentage rise in cellulose and fall in crude protein than did year 1 . However, in year 2 , there was a large percentage lignin increase during the growing season, while in year 1 there was a decrease in lignin percentage (Table 2).

The relationship in our study between coarse particles in the rumen and high forage quality support the contention of Troelsen and Campbell (1968) that particle size may have little influence on rate of passage and intake until the forage reaches a maturity stage where the reticulo-omasal orifice begins to restrict passage. Allinson and Osbourn (1970) reported long days and high temperatures lowered in vitro cellulose digestibility of tall fescue (Festuca arundinacea). We speculate that earlier maturity would increase the inhibitory effect of particle size on rate of passage and intake at an earlier date resulting in slower rumen turnover and more complete breakdown of particles. That is illustrated by the rise $(P<10)$ in fine and very fine particle percentages during the year 2 growing season, while year $i$ showed no rise $(P<.10)$ when compared with early season percentages (Fig. 2).

\section{Influence of Season and Site on Rumen Particle Sizes.}

Percentages of particle sizes in the rumen varied among rumen sites and were influenced by seasonal changes during both study years (Fig. 3 and 4 ). Both years show a significantly $(P<.10)$ greater amount of coarse material during all seasons in the dorsal region of the rumen than the ventral or reticular areas. Significantly greater $(P<.10)$ percentages of medium, fine, and very-fine particles were present during all seasons at the reticulum and ventral sites than

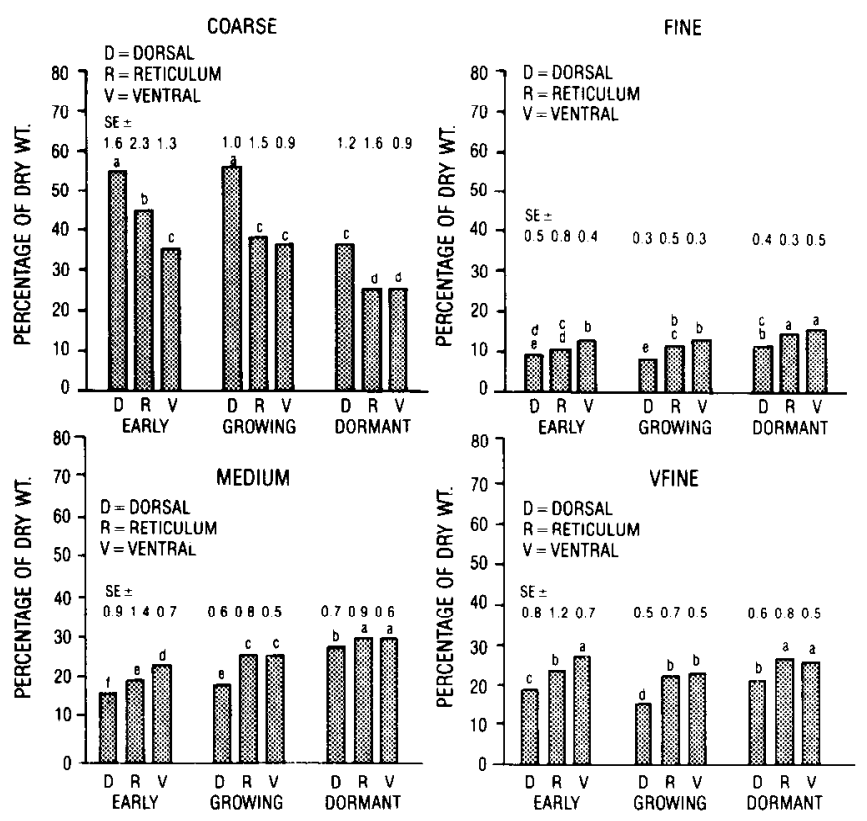

Fig 3. Year 1 (1979-80) percentage of cattle rumen digesta particles present at dorsal, ventral and reticular sites during early, growing and dormant seasons. Bars with common letters are not significantly different $(\alpha=$ $.10)$.

the dorsal site. Researchers have been aware of rumen stratification and have acknowledged its relationship to the digestive process for some time (Schalk and Amadon 1928).

Percentages of coarse particles at dorsal, ventral, and reticular sites during both study years decreased $(P<.10)$ with advancing season probably due to decreasing forage quality (Fig. 3, 4). Percentages of medium and fine particles rose $(P<10)$ at those sites as forage matured, reflecting longer rumen retention and greater extent of comminution.

Very-fine particle percentages during the year 2 dormant season were no greater $(P<.10)$ than during the previous 2 periods. That 

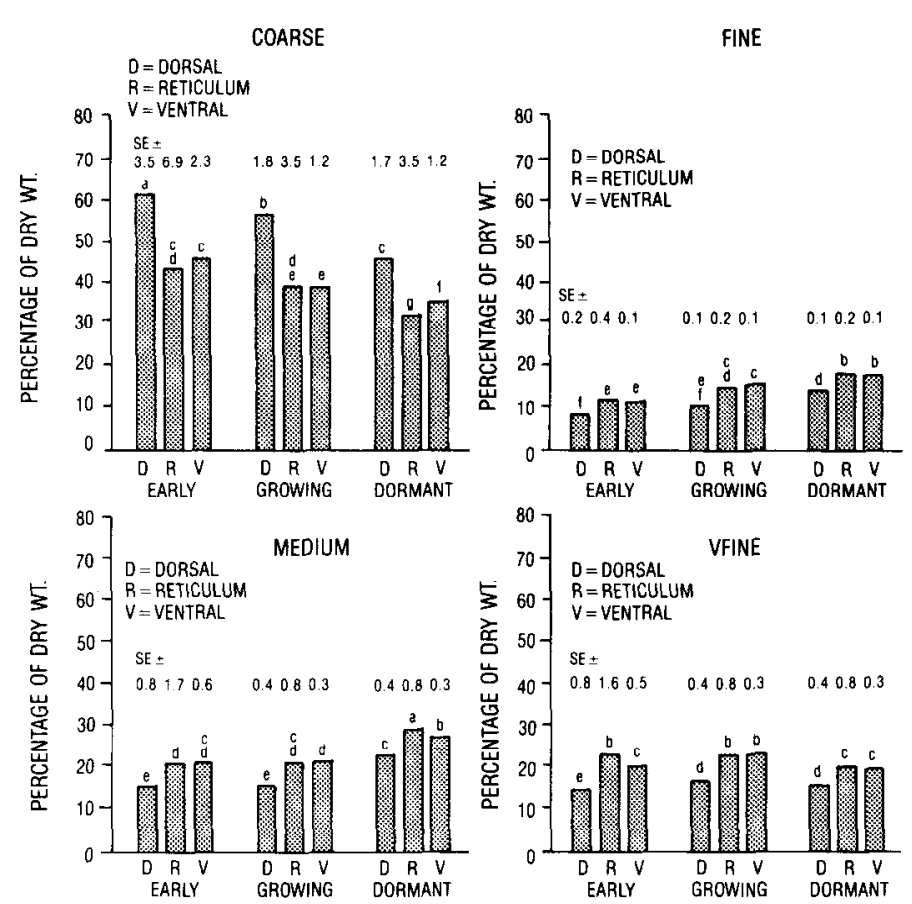

Fig. 4. Year 2(1980-81) percentage of cattle rumen digesta particles present at dorsal, ventral, and reticular rumen sites during early, growing and dormant seasons. Bars with common letters are not significantly different $(\alpha=.10)$.

may be due to advaneed forage maturity during the growing scason, but does not explain its similarity to the early season.

Year I very-fine percentages were less $(P<10)$ during the growing season than the early season. There was also no increase $(P<10)$ in growing season percentages of fine particles compared to early season percentages. That possibly reflects the effects on the forage of mild temperatures and above-average moisture during much of the year I growing season.

With few exceptions, percentages of all particle sizes during all seasons were the same $(P<.10)$ at ventral and reticular sites. That was not unexpected as small well-saturated particles that sink to the ventral rumen are carried by flow of rumen fluid to the reticulum for subsequent passage to the omasum (Church 1976).

Influence of Sampling Time and Site on Rumen Particle Size.

AM samples were taken after the cattle had fasted for about 16 hours, while PM samples were taken 12 hours post-feeding during both study years. Comparison of particle concentrations at these 2 sample times and the PRE sample taken during year 2 allows comparison of increasing rumen retention times on breakdown of native range forage (Fig. 5 , year 1 data not shown).

There was a progressive decrease $(P<.10)$ in the amount of coarse material present as rumen residence time nncreased (AM $<$ $\mathrm{PM}<\mathrm{PRE}$ ). Greater percentage of coarse material coincided with shorter rumen exposure time and less comminution of digesta via rumination and microbial attack. Evans et al. (1973) showed maximum concentrations of coarse particles at dorsal sites immediately after feeding and a uniform decrease thereafter. Pearce (1967) reported coarse percentages in the rumen fell rapidly between 12 and 24 hours.

Ventral and reticular sites were shown to have minimum concentrations of coarse particles immediately after feeding (Evans et al. 1973). Our study showed significantly greater amounts $(P<10)$ or no differences at these sites as sample times were closer to feeding.

The reason for lower percentage of coarse material present at ventral vs. reticular sites is unknown. Other work shows that phenomenon (Evans et al. 1973). While AM and PM ventral concentrations of coarse material were less than reticulum values
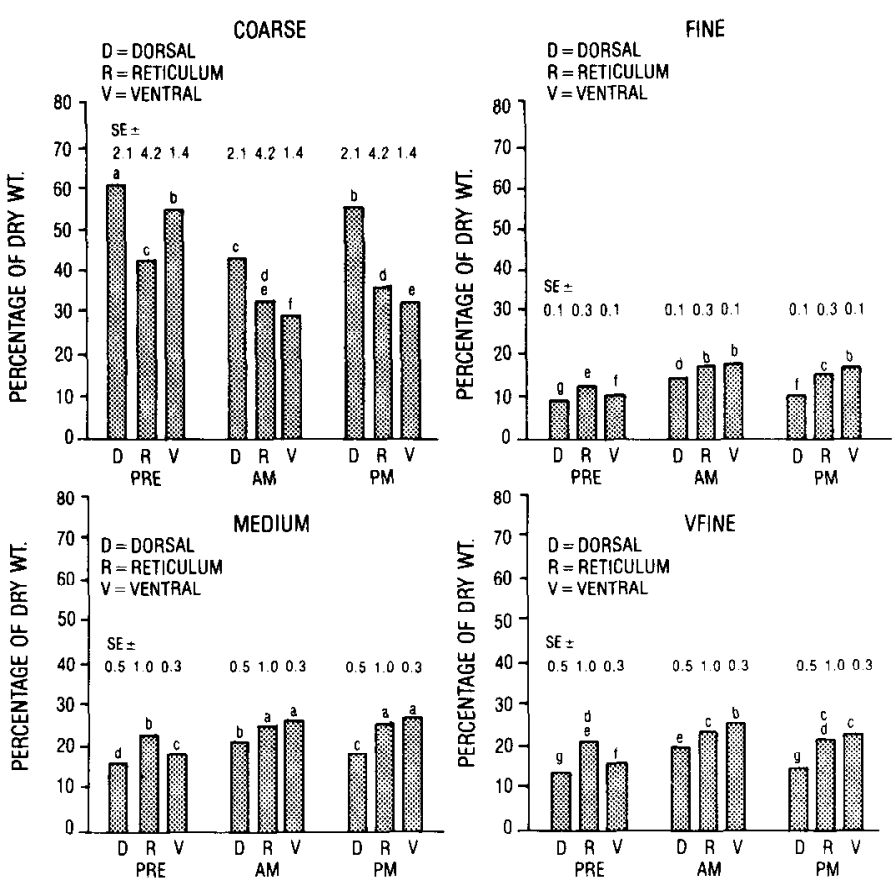

Fig. 5. Year 2(1980-8I) percentage of cattle rumen digesta particles present at dorsal, ventral, and reticulum rumen sites during $P R E, A M$, and $P M$ sample times. Bars with common letters are not significantly different ( $\alpha$ $=.10$ ).

during both years, the percentage of coarse material in the ventral site of PRE samples was greater than that in the reticulum $(P<10)$. The reticulum receives digesta, mainly fluid and small particles of high density (Church 1976) from the ventral rumen; however. Evans et al. (1973) indicated digesta in general moves to the reticulum as it cycles around the rumen. The great volume of coarse material at the dorsal site may have physically prevented movement to the reticulum of any coarse particles contained in the ventral rumen
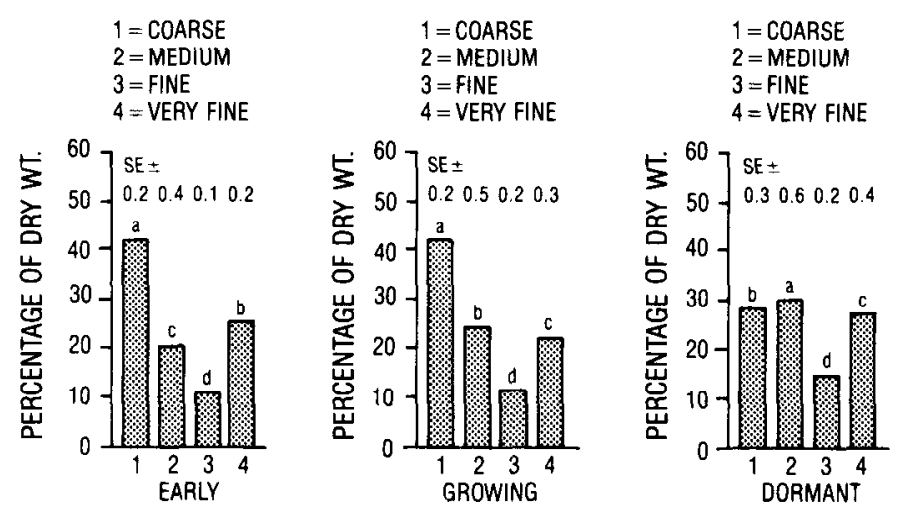

Fig. 6. Percentages of particle size present in cattle rumens at early. growing and dormant seasons during Year I (1979-80). Bars with common letters are not significantly different $(\alpha=.05)$.

Medium size particle percentages during both years did not vary greatly between $A M$ and $P M$ samples at ventral and reticulum sites $(P<10)$, but these times both had greater medium percentages than the PRE sample. Medium particles varied more at the dorsal site where they increased as rumen residence time of digesta increased $(A M>P M>P R E)$.

The AM samples showed greater $(P<.10)$ dorsal site fine particles and greater or similar percentages at the reticulum and ventral site than PRE and PM samples. Results from Evans et al. (1973) were similar 


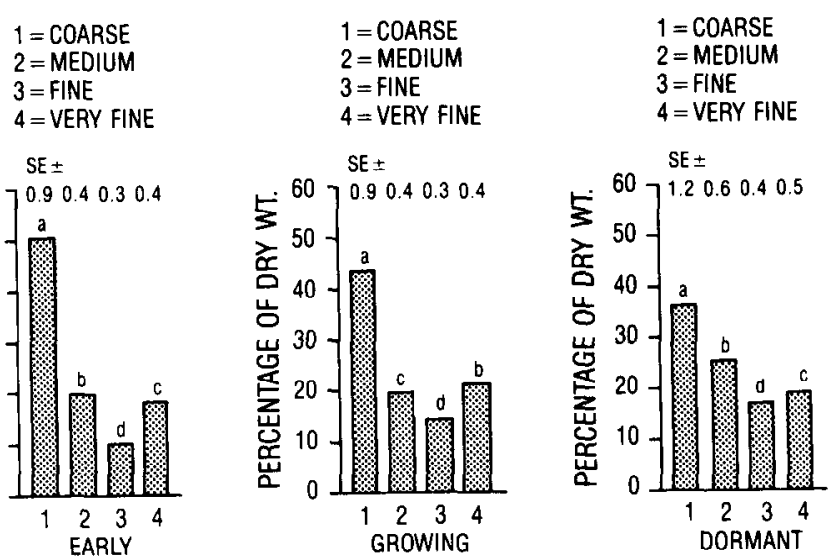

Fig. 7. Percentages of particle sizes present in cattle rumens at early, growing, and dormant seasons during Year 2(1980-81). Bars with common letters are not significantly different $(\alpha=.05)$.

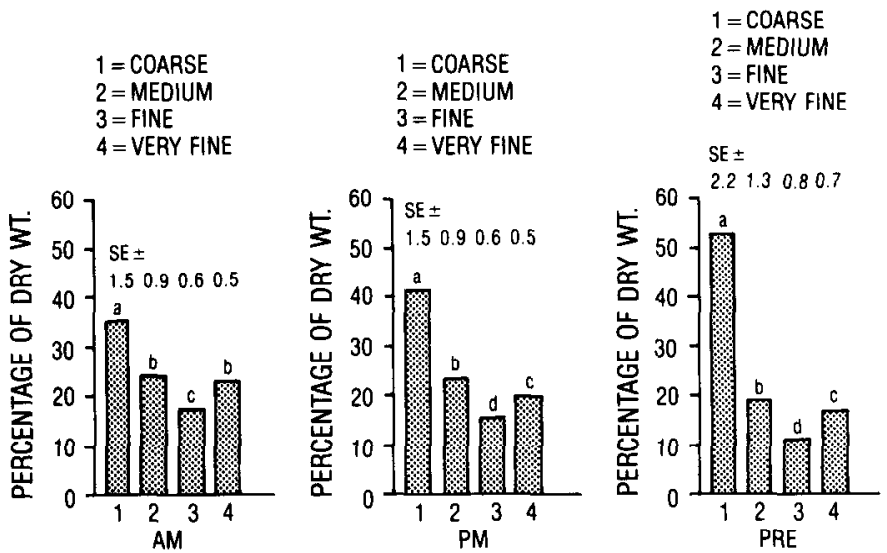

Fig. 8. Percentages of particle sizes found in cattle rumens in PRE, $A M$, and $P M$ sample times during Year 2 (1980-81). Bars with common letters are not significantly different $(\alpha=.05)$.

Very-fine particle percentages were greatest $(P<.10)$ (with one exception) at the AM time followed by PM and PRE times. That agrees with Evans et al. (1973) and again reflects the effect of longer rumen residence time on particle breakdown.

\section{Comparison of Total Rumen Particle Percentages by Seasons}

As shown previously in this study and by Balch (1961) and Evans et al. (1973), rumen digesta becomes more homogenous with longer retention times. Our data (Fig. 6,7 ) show relative differences $(P<.05)$ in percentages of particles sizes to be less during dormant seasons both years.

Fine particles were lowest in percentages of any size during all seasons.

\section{Comparison of Total Rumen Particle Percentages by Time}

Percentages of the 4 particle sizes measured were different at all sample times both study years $(P<.05$ ). Only year 2 (Fig. 8 ) is shown. Our study and others (Troelsen and Campbell 1968, Evans et al. 1973) show lesser amounts of coarse and greater amounts of small particles and a smaller difference between particle sizes as rumen retention time increased $(\mathrm{AM}>\mathrm{PM}>\mathrm{PRE})$.

\section{Influence of Years and Seasons of Fecal Particle Sizes}

Similar to rumen samples, percentages of coarse particles decreased and smaller particles increased $(P<10)$ in the feces as seasons advanced (Fig. 9). Our results do not agree with those of Hellstrom and Aamisepp (1965), who fed ryegrass (Lolium sp.) and cocksfoot (Dactylis sp.) to sheep and separated particles with ultrasonic irradiation.

Fecal sample percentages were more similar among particle sizes
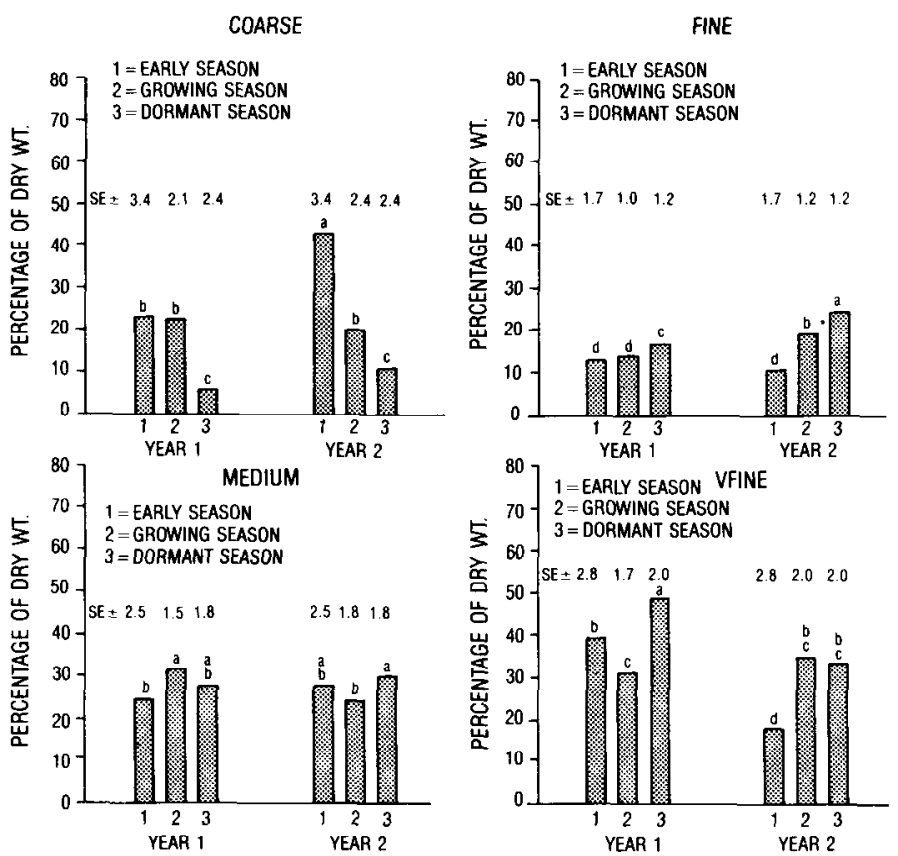

Fig. 9. Year 1(1979-80) and 2(1980-81) percentages of fecal particles from cattle present during early, growing, and dormant seasons. Bars with common letters are not significantly different $(=.10)$.

$$
\begin{aligned}
& 1=\text { COARSE } \\
& 2=\text { MEDIUM } \\
& 3=\text { FINE } \\
& 4=\text { VERY FINE }
\end{aligned}
$$

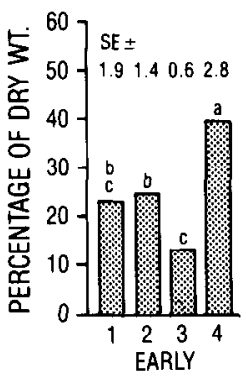

Fig. 10. Percentages of particle sizes present in cattle feces at early, growing, and dormant seasons during Year 1 (1979-80). Bars with common letters are not significantly different $(\alpha=.05)$.
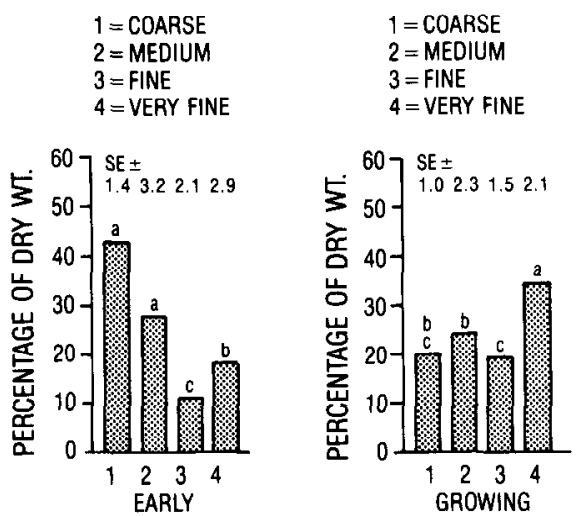

$1=$ COARS

$2=$ MEDIUN

$3=$ FINE

$4=$ VERY FINE

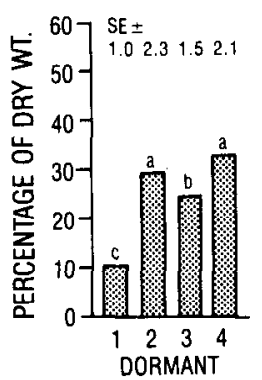

Fig. 11. Percentages of particle sizes present in cat le feces at early, growing and dormant seasons during Year 2 (1980-1981). Bars with common letters are not significantly different $(\alpha=.05)$. 
than were rumen samples (Fig. 10,11) due to the 'sieving' done by the reticulo-omasal orifice, which results in a more uniform fecal particle size. For the same reason, the feces also contain greater percentages of very-fine than coarse particles; however, greater percentages of large fecal particles were found in the early season.

Our study shows the range-forage:rumen-function interaction that occurs with advancing maturity of Kansas Flint Hills range. Our results are for the most part similar to those done under housed conditions. With greater forage maturity, greater percentages of small particles are found in the rumen. That indicates lengthened rumen turnover time, intake, and reduced productivity compared to less mature forage. Utilization of data found here may aid further development of forage management practices emphasizing proper season of use (Smith and Owensby 1978) and methods facilitating microbial attack and breakdown of forage in the rumen.

\section{Literature Cited}

Akin, D.E., E.L. Robinson, F.E. Barton, III and D.S. Himmelsbach. 1977. Changes with maturity in anatomy, histochemistry, and chemistry and tissue digestibility of bermudagrass plant parts. J. Agr. Food Chem. 25: 179.

Allinson, D.W., and D.F. Osbourn. 1970. The cellulose-lignin complex in forages and its relationship to forage nutritive value. J. Agr. Sci. Camb. $74: 23$

Balch, C.C. 1961. Movement of digesta through the digestive tract. In: Digestive Physiology and Nutrition of the Ruminant. (Lewis, D., ed.) Butterworths, London.

Balch, C.C., and R.C. Campling. 1965. Rate of passage of digesta through the ruminant digestive tract. In: Physiology of Digestion in the Ruminant (Dougherty, R.W., ed.) Butterworths, London.

Blaxter, K.L., N. McC. Graham, and F.W. Wainman. 1956. Some observations on the digestibility of food by sheep and on related problems. Brit. J. Nutr. 10-69.

Blaxter, K.L., F.W. Wainman, and R.S. Wilson. 1961. The regulation of food intake by sheep. Anim. Prod. 3:51.

Church, D.C. 1976. Digestive physiology and nutrition of ruminants. I. Digestive Physiology. Metropolitan Publ. Co., Portland, Ore.

Duncan, D.B. 1955. Multiple range and multiple $F$ tests. Biometrics. $11: 1-42$.
Evans, E.W., G.R. Pearce, J. Burnett, and S.L. Pillinger. 1973. Changes in some physical and characteristics of the digesta in the reticulo-rumen of cows fed once daily. Brit. J. Nutr. 29:357.

Forwood, J.R. 1982. I. Nutrient removal rates from ruminoreticulms of cattle grazing Kansas Flint Hills range. Ph.D. Diss. Kansas State Univ., Manhattan.

Gill, J., R.C. Campling, and D.R. Westgarth. 1966. A study of chewing during eating in the cow. Brit. J. Nutr. 20:13.

Goering, H.K., and P.J. VanSoest. 1970. Forage fiber analyses (apparat us, reagents, procedures and some applications). ARS USDA Handbk. No. 379.

Hellstrom, N., and M. Aamisepp. 1965. Faecal analyses and digestibility. J. Sci. Fd. Agr. 16:27.

Hungate, R.E. 1966. The Rumen and its Microbes. Academic Press, New York and London.

Johnston, M.J., and R. Waite. 1965. Studies in the lignification of grasses. J. Agr. Sci. 64:211.

Patton, A.R., L. Gieseker. 1942. Seasonal changes in the lignin and cellulose content of some Montana grasses. J. Anim. Sci. 1:22.

Pearce, G.R. 1967. Changes in particle size in the reticulorumen of sheep. Aust. J. Agr. Res. 18:119.

Pearce, G.R., and R.J. Moir. 1964. Rumination in sheep. I. The influence of rumination and grinding upon passage and digestion. Aust. J. Agr. Rex. 15:635.

Schalk, A.M., and R.S. Amadon. 1928. Physiology of the ruminant stomach. N. Dak. Agr. Exp. Sta. Bull. 216.

Silver, E.A., P. Gerlaugh, C.W. Gay, A.F. Schlak, and C.H. Kick. 1935. Preparation of feeds for cattle as it affects digestibility and adsorption. Agr. Eng. 16:257.

Smith, E.F., and C.E. Owensby. 1978. Intensive early stocking and seasonlong stocking of Kansas Flint Hills ranges. J. Range Manage. 31:14.

Steel, G.D., and J.H. Torrie. 1960. Principles and procedures of statistics. McGraw-Hill Book Co., New York.

Troelsen, J.E., and J.B. Campbell. 1968. Voluntary consumption of forage by sheep and its relation to the size and shape of particles in the digestive tract. Anim. Prod. 10:289.

Welch, J.G., and A.M. Smith. 1978. Particle sizes passed in the rumen. J. Anim. Sci. 46:309.

Wilkins, R.J. 1972. The potential digestibility of cellulose in grasses and its relationship with chemical and anatomical parameters. J. Agr. Sci., Camb., 78:457. 